\title{
Gangrena de Fournier con afectación uretral: reepitelización uretral con tratamiento conservador
}

L. Gómez Pérez, F.J. Delgado Oliva, V. Gimeno Argente, S. Arlandis Guzmán, B. Arce Casado, F.J. Jiménez Cruz

Servicio de Urología. Hospital Univ. La Fe. Valencia. *Hospital General Virgen de la Luz. Cuenca.

Actas Urol Esp 2006; 30 (1): 101

$\mathrm{V}$ arón de 48 años sin antecedentes de interés, que presenta un cuadro de Gangrena de Fournier con afectación uretral de unos $4 \mathrm{~cm}$ (Fig. 1), tras un episodio de uretritis. Se realizó un tratamiento quirúrgico inicial consistente en escisión amplia de los tejidos necróticos, junto con antibioterapia de amplio espectro, analgesia intravenosa y derivación de la orina, seguido de curas diarias con apósitos hidrocoloides. En la uretrografía retrógrada realizada a las tres semanas, se observa la restitución anatómica de la uretra (Fig. 2) y funcional, con un $3 \max$ de 25 $\mathrm{ml} / \mathrm{s}$ en la flujometría de control, por lo que no fue precisa una uretroplastia posterior como hubiera sido de esperar.

Dr. L. Gómez Pérez

E-mail: luisgope@hotmail.com

(Trabajo recibido el 22 de septiembre 2005)

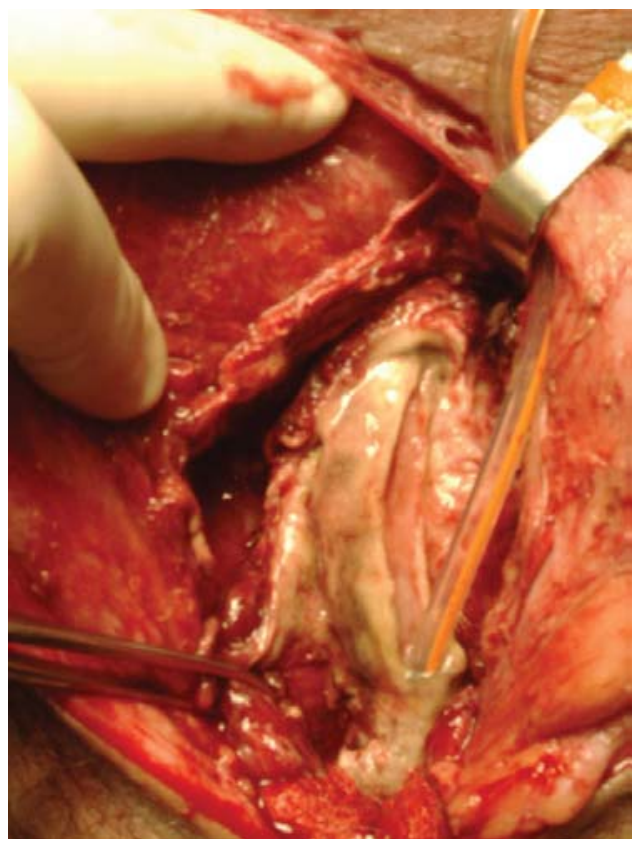

FIGURA 1. Defecto uretral.

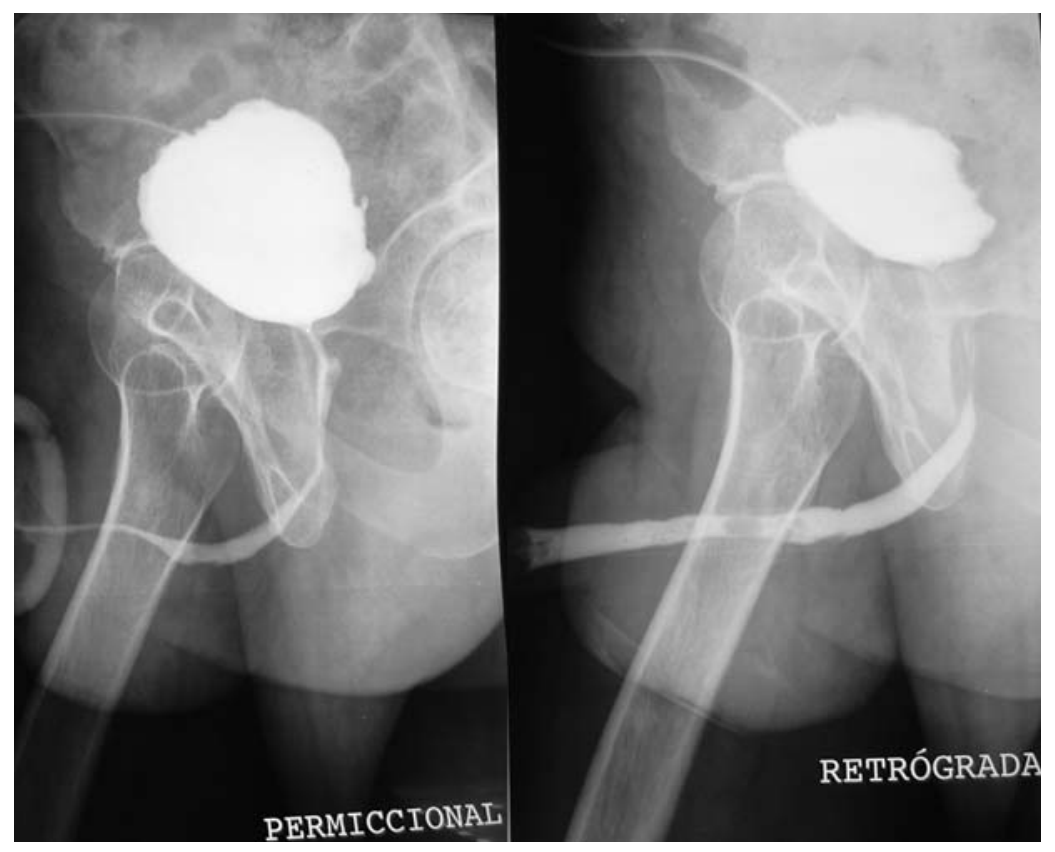

FIGURA 2. Uretrografía. 